\title{
Population Estimation of Oncorhynchus mykiss, Salmo trutta and Schizothorax plagastimous in Upper River Swat, Khyber Pakhtunkhwa, Pakistan
}

\author{
Khan $\mathrm{T}^{1}$, Hayat $\mathrm{S}^{2}$, Ullah $\mathrm{F}^{3 *}$, Hayat $\mathbf{H}^{4}$, Ali $\mathrm{S}^{2}$, \\ Khan $\mathrm{S}^{5}$ and $\mathbf{A h m a d} \mathbf{M}^{1}$ \\ ${ }^{1}$ Department of Fisheries and Aquaculture, University of \\ Veterinary \& Animal Sciences, Pakistan \\ ${ }^{2}$ Department of Livestock \& Dairy Development, Khyber \\ Pakhtunkhwa, Pakistan \\ ${ }^{3}$ Lasbela University of Agriculture, Water and Marine \\ Sciences, Pakistan \\ ${ }^{4}$ Department of Pathology, University of Veterinary and \\ Animal Sciences, Pakistan \\ ${ }^{5}$ Department of Dairy Technology, University of \\ Veterinary \& Animal Sciences, Pakistan \\ *Corresponding author: Farman Ullah, Lasbela \\ University of Agriculture, Water and Marine Sciences, \\ Faculty of Veterinary and Animal Sciences, Uthal, \\ Balochistan, Pakistan
}

Received: January 12, 2021; Accepted: February 03, 2021; Published: February 10, 2021

\section{Introduction}

RIVER Swat starts from Mahoo Dhand at an elevation of about 3,000 meters, passes through the valley of Swat and flows for about 160 kilometer across the valley up to Chakdara. Total length of the river is 250 kilometers from Kalam to river Kabul near Charsadda. River Swat provides habitat for various fish species especially the trout in the upper part. The valley is mainly known for its abundant fish resources [1]. Trout belong to the group of fishes known as Salmonids. The typical coloration of rainbow trout is blue to olive green above the lateral line, a pink band along the lateral line and silver below the lateral line. Brown trout have generally some shade of brown on the back and side, fading to yellow on the belly, spots are large and black [2].

\section{Materials and Methods}

\section{Permission from fishery department}

Before starting the field work, permission was obtained from the Fishery Department, Khyber Pakhtunkhwa and a research officer of the Trout Culture \& Training Center (TCTC) Madayn, Swat was deputed by the department for technical assistance \& facilitating the work.

\section{Site selection}

The subareas selected for fish capturing were: Madyan, Mankiyal, Kalam, and Mahoo Dhand indicated as $\mathrm{SA}_{1}, \mathrm{SA}_{2}, \mathrm{SA}_{3}, \mathrm{SA}_{4}$, respectively.

\section{Fish capturing}

Fishes were captured through electrofisher, a common scientific survey method used to sample fish populations to determine abundance, density, and species composition [3-5]. Electrofishing caused no permanent harm to fish and fish usually returned to their natural state in as little as two minutes after being stunned. The captured fishes were identified on the basis of morphological characteristics.

\section{Statistical analysis}

The data were analysed by Analysis of Variance (ANOVA) through SAS 9.1 statistical software and Duncan's Multiple Range Test (DMRT) was applied to compare means [6].

\section{Results and Discussion}

The studies were conducted at four Sub-Areas (SAs) of the upper river Swat viz: Madyan, Mankiyal, Kalam and Mahoo Dhand denoted by short words of $\mathrm{SA}_{1}, \mathrm{SA}_{2}, \mathrm{SA}_{3}$ and $\mathrm{SA}_{4}$, respectively. The details of captured fishes from each sub-area are given as under.

\section{Subarea madyan $\left(\mathrm{SA}_{1}\right)$}

From SA1, 64 fishes (56 S. plagastimous and 8 O. mykiss) were captured. Mean wet weight of S. plagastimous and O. mykiss was as recorded as $121.85 \pm 46.24 \mathrm{~g}$ and $130.25 \pm 45.02 \mathrm{~g}$ whereas mean body length of $S$. plagastimous and O. mykiss was as recorded as was recorded as $20.73 \pm 3.80 \mathrm{~cm}$ and $21.75 \pm 2.5 \mathrm{~cm}$, respectively. The relative abundance of S. plagastimous and O. mykiss was $87.5 \%$ and $12.65 \%$, respectively (Table 1 ).

\section{Subarea mankiyal $\left(\mathrm{SA}_{2}\right)$}

From SA2, 106 fishes (84 S. trutta, 14 S. plagastimous and 8 O. mykiss) were captured. Mean wet weight of Salmo trutta, S. plagastimous and O. mykiss was as recorded as $117.69 \pm 64.79 \mathrm{~g}$, $155.85 \pm 59.18$ and $113.5 \pm 81.17 \mathrm{~g}$ whereas mean body length of $S$. trutta, S. plagastimous and O. mykiss was as recorded as was recorded 
Table 1: Data of Fishes Captured At Madyan ( $\left.\mathrm{SA}_{3}\right)$.

\begin{tabular}{|c|c|c|c|c|}
\hline Sub-area & Species & Captured fishes & Length (cm \pm SD) & Weight (gm \pm SD) \\
\hline \multirow{2}{*}{ Mad-yan $\left(\mathrm{SA}_{1}\right)$} & O. mykiss & 8 & $21.75 \pm 2.5$ & $130.25 \pm 45.02$ \\
\cline { 2 - 5 } & S. plagastimous & 56 & $20.73 \pm 3.80$ & $12.65 \%$ \\
\hline
\end{tabular}

Table 2: Data Of Fishes Captured At Mankiyal $\left(\mathrm{SA}_{2}\right)$.

\begin{tabular}{|c|c|c|c|c|}
\hline \multirow{2}{*}{ Site } & Species & Captured fishes & Length (cm \pm SD) & Weight (gm \pm SD) \\
\hline \multirow{2}{*}{ Mank-iyal $\left(\mathrm{SA}_{2}\right)$} & S.trutta & 84 & $20.84 \pm 4.60$ & $117.69 \pm 64.79$ \\
\cline { 2 - 5 } & O.mykiss & 8 & $20 \pm 5.71$ & $113.5 \pm 81.17$ \\
\cline { 2 - 5 } & S.plagastimous & 14 & $23.42 \pm 3.50$ & $15.54 \%$ \\
\hline
\end{tabular}

Table 3: Data of Fishes Captured At Kalam $\left(\mathrm{SA}_{2}\right)$.

\begin{tabular}{|c|c|c|c|c|}
\hline Sub-area & Species & Captured fishes & Length (cm \pm SD) & Weight (gm \pm SD) \\
\hline \multirow{2}{*}{ Kalaml $\left(\mathrm{SA}_{3}\right)$} & O. mykiss & 112 & $22.85 \pm 5.44$ & $141.80 \pm 76$ \\
\cline { 2 - 5 } & S. plagastimous & 14 & $20.83 \pm 2.78$ & 0.44 \\
\hline
\end{tabular}

Table 4: Data of fishes captured at Mahoo Dhand $\left(\mathrm{SA}_{4}\right)$.

\begin{tabular}{|c|c|c|c|c|}
\hline Sub-area & Species & Captured fishes & Length (cm \pm SD) & Weight (gm \pm SD) \\
\hline \multirow{2}{*}{ Mahoo Dhand $\left(\mathrm{SA}_{4}\right)$} & O. mykiss & 180 & $24.23 \pm 5.278$ & $162.37 \pm 75.04$ \\
\cline { 2 - 5 } & S. plagastimous & 26 & $26.64 \pm 6.046$ & $194.85 \pm 86.94$ \\
\hline
\end{tabular}

as $20.84 \pm 4.60 \mathrm{~cm}, 23.42 \pm 3.50 \mathrm{~cm}$ and $20 \pm 5.7 \mathrm{~cm}$, respectively. The relative abundance for S. trutta, S. plagastimous and O. mykiss was $79.24 \%, 13.20 \%$ and $7.54 \%$, respectively (Table 2).

\section{Subarea kalam $\left(\mathrm{SA}_{3}\right)$}

From SA3, 126 fishes (112 S. trutta and 14 O. mykiss) were captured. Mean wet weight of $S$. trutta and O. mykiss was as recorded as $141.80 \pm 76.44 \mathrm{~g}$ and $110 \pm 39.88 \mathrm{~g}$ whereas mean body length of $S$. trutta and $O$. mykiss was recorded as $22.85 \pm 5.44 \mathrm{~cm}$ and $20.83 \pm 2.78$ $\mathrm{cm}$, respectively. The relative abundance of $S$. trutta and $O$. mykiss was $88.89 \%$ and $11.11 \%$ (Table 3 ).

\section{Subarea mahoo dhand $\left(\mathrm{SA}_{4}\right)$}

From SA4, 206 fishes (180 S. trutta and 26 O. mykiss) were captured. Mean wet weight of $S$. trutta and O. mykiss was as recorded as $162.37 \pm 75.04$ and $94.85 \pm 86.94 \mathrm{~g}$ whereas mean body length of $S$. trutta and $O$. mykiss was recorded as $24.23 \pm 5.278 \mathrm{~cm}$ and $26.64 \pm 2.78$ $\mathrm{cm}$, respectively. The relative abundance of $S$. trutta and O. mykiss was $87.37 \%$ and $12.62 \%$, respectively (Table 4 ). The results of the present study are in line with the results of $[7,8]$ regarding the fish diversity of river Swat. In the same way, results of [9] regarding length of the 96 trout fishes $(13.0-88.4 \mathrm{~cm})$ also support this study. The highest capture at $\mathrm{SA}_{4}$ is probably due to least water temperature and highest dissolved oxygen [essential for trout survival] as compared to other areas.

\section{Conclusion}

From the present study it is concluded that upper parts of river Swat (especially river part from Mankiyal to Mahoo Dhand) provide a rich habitat $S$. trutta and $O$. mykiss species of trout.

\section{Acknowledgment}

The authors are indebted to Mr. Jaffar Yahya, Research Officer and all the team of Government Trout Culture and Training
Center (TCTC) Madyan, Swat, for their technical assistance and for supplying the facilities, equipment and time necessary to complete the field work.

\section{References}

1. Hayat R. Saving of river swat from growing pollution. 2007.

2. Petr T, Swar DB. Cold water fisheries in the trans-Himalayan countries, FAO Fisheries Technical Paper. Rome. 2002; 431: 364.

3. Bohlin T, Hamrin S, Heggberget TG, Rasmussen G, Saltweit SJ. Elctrofishing theory and practice with special emphasis on salmonids. Hydrobiologia. 1989; 173: 9-43.

4. Thompson PD, Rahel FJ. Evaluation of depletion-removal electrofishing of brook trout in small Rocky Mountain streams. North American Journal of Fisheries Management. 1996; 16: 332-339.

5. Zippin C. The removal method of population estimation J. Wild management. 1958; 22: 82-90.

6. AOAC. Official methods of analysis of AOAC (Association of Official Analytical Chemists) $18^{\text {th }}$ Edi. Horwitz W, editor. AOAC International: Publishing. Gaithersburg, Maryland. 2006.

7. Mirza MR. Biologia Pakistan. 2007; 53: 109-112.

8. Hasan Z, Ibrar A, Muhammad Y, Latif UR, Jahangir K. Fish biodiversity of river Swat. Pakistan J zool. 2013; 45: 283-289.

9. Hatlevik SP. The lake trout of Tutshi lake life history and preliminary assessment of annual sustainable yield. British Columbia Ministry of Environment Fish and Wildlife Branch Smithers, B.C. Skeena Fisheries. 1987.

10. Asian Development Bank. Pakistan Aquaculture Development Project Feasibility Study. Aquatic Farm Ltd. Honolulu Hawaii USA. 1984; 232.

11. Bernhard M. Manual of methods in aquatic environment research, part 3 : sampling and analyses of biological material. FAO Fish Tech. 1976.

12. Blackburn J. Population abundance and stock assessment of westslope cutthroat trout in the upper Oldman River watershed. Data report, by the Alberta Conservation Association, Lethbridge, Alberta, Canada. 2008; 38: 50-61. 
13. Hassan A, Ishaq M, Farooq A, Sadozai SH. Economics of trout fish farming in the northern areas of Pakistan, Sarhad J Agric. 2007; 23: 407-410.

14. SAS. Statistical Analysis Systems. Program 6; SAS institute incorporation. Cary. NC 27513. USA, 2000

15. Wilson D. Report on the 2001 stock assessment of the river Darwen catchment Environment agency Lutra house, Dodd way Walton Summit Bamber Bridge Preston PR5 8X. 2002.
16. Yaqoob M. Cold Water Fisheries of Pakistan, Aquaculture \& Fisheries Research Institute, National Agriculture Research Centre, Park Road Islamabad, Pakistan. 2002 